\title{
IEEJ Journal of Industry Applications Vol. 3 No.2 \\ Special Issue on “Motor Drive and its Related Technologies”
}

ゲストエディタ 長谷川 勝 (中部大学)

産業応用部門では国際化を推進しており，多様化する国際社会に学術的に貢献し，国内の良質な論文を海 外に積極的に発信するために IEEJ Journal of Industry Applications（電気学会英文論文誌 D）を 2 ケ月に 1 回発 刊しています。IEEJ Journal of Industry Applications はフリーダウンロード可能ですので，是非 https://www.jstage.jst.go.jp/browse/ieejjiaにアクセスください。

英文論文誌 3 月号では, Vol.1, No.3(2012 年 11 月号)に続くモータドライブ技術と関連技術に関する特集号 を企画いたしました。これらの技術は産業応用部門にとって極めて重要な技術分野の一つであることから， それらの技術動向を明確にして世界に発信することは学界・産業界にとって有意義なことと考えます。

今回の特集号では，モータドライブ関連技術の中で最も多くの技術が研究発表され，注目を集めている永 久磁石同期電動機の位置センサレス制御を取り上げました。Review Paper として，海外での研究動向ならび に実用化の状況をサーベイした論文を 2 編ご投稿いただきました。位置センサレス制御最前線とも言える内 容になっておりますので，ぜひご一読ください。これ以外にも Original Paper としてご投稿頂いた特集論文 を掲載しております。なお，これらの投稿論文は，電気学会の査読プロセスで厳正に採否が決定されている ものであり，品質の高い特集企画になっていると自負しております。最後に，特集号を発行するにあたり， 論文を投稿いただいた著者の皆様，査読にご尽力をいただきました方々，並びに特集号発行にご尽力頂いた ご関係各位に感謝の意を表します。

\section{【論文誌 D 3 月号特集「産業計測制御・メカトロニクス制御全般」案内】}

\section{平成 25 年産業計測制御研究会プログラム担当 柴田 昌明（成蹊大学）}

産業計測制御，メカトロニクス制御一般に関する技術は，産業界における生産性・品質向上や安全性の確 立，日常における生活の向上などに対して極めて重要であり，それらの技術動向を明確にすることは学界・ 産業界にとって意義が深いものがあります。産業計測制御技術委員会（IIC）では例年 3 月に産業計測制御研 究会を開催しておりましたが，平成 25 年 1 月に新しく発足したメカトロニクス制御技術委員会（MEC）と 共同して，同年 3 月に産業計測制御・メカトロニクス合同研究会を開催しました。研究会テーマを「産業計 測制御・メカトロニクス制御全般」に広げて，IIC および MEC 傘下のすべての調查専門委員会および協同研 究委員会が一同に協賛する盛大な研究会となりました。今回の合同研究会 (平成 25 年 3 月 7 日〜 8 日, 千葉 大学）では，発表件数 152 件という規模になり，質の高い発表とともに活発な討論が行われました。このよ うな背景のもと，産業計測制御・メカトロニクス制御全般に関する論文をできる限り集約して読者の目に触 れやすくすると同時に, 本研究会で発表された研究成果とそこで交わされた有意義な議論を広く共有するた めに，論文誌 D 平成 26 年 3 月号で「産業計測制御・メカトロニクス制御全般 特集号」を企画致しました。

本特集号では, 平成 25 年 3 月の産業計測制御・メカトロニクス制御合同研究会において口頭発表された論 文をべースに，研究会における質疑やコメント等の討議結果を踏まえて投稿され査読を経た論文を，特集論 文としてまとめて掲載致します。(https://www.jstage.jst.go.jp/browse/ieejias /-char/ja/)

なお, 平成 26 年 3 月にも合同研究会を開催し, 引き続き本特集号と同様の企画を継続することにしており ます。研究会でのご発表と発表された内容を論文化することをぜひご検討いただき，奮ってご投稿ください ますようお願い申し上げます。 